\title{
Passive Hemagglutination for Detection of Autoantibodies against Thyroglobulin in Dogs
}

Primary hypothyroidism in dogs is mainly caused by autoimmune thyroiditis or idiopathic follicular atrophy of the thyroid gland (Gosselin et al. 1982). Serologically, autoimmune thyroiditis can be diagnosed by detection of autoantibodies against thyroid antigens in hypothyroid dogs (Mizejewski et al. 1971, Gosselin et al. 1980). Passive hemagglutination test (PHT) has been the serological test, most widly used for detection of antibodies (Mizejewski et al. 1971, Gosselin et al. 1982, Vollset \& Larsen 1987).

The most time-consuming procedures in connection with the PHT are the preparation of antigens, the collection and preparation of red blood cells and the coating of red blood cells with antigens. Preparation of thyroglobulin coated sheep red blood cells (SRBC) in large amounts and subsequent freezing in several small ampullae may be both time saving and may eliminate errors due to batch to batch variability.

The aim of this study was therefore to establish a PHT using erythrocytes coated with thyroid globulins stored at $-196^{\circ} \mathrm{C}$.

Serum sampling, preparation and isolation of thyroglobulin and PHT using the chromic chloride method $(\mathrm{CCH})$ and the glutaraldehyde method $(\mathrm{GCH})$, were as described by Gosselin et al. (1980), Avrameas et al. (1969), Vollset \& Larsen (1987).

A human hemagglutination kit (Thymune$\mathrm{T}^{\mathrm{R}}$, Wellcome) based on freezedried tanned turkey erythrocytes coated with human thyroglobulin was also tested.
The PHT was performed in microtiter Vbottom plates with two-fold dilutions of test serum and mixed with coated $\mathrm{RBC}$ to a final $\mathrm{RBC}$ concentration of $0.33 \%$ in all $3 \mathrm{me}-$ thods used. The PHT results were not influenced when SRBC were collected from different animals. For cryopreservation of thyroglobulin coated SRBC, the cells were suspended in gelatin-veronal-buffered salinesucrose (GVBSM ${ }^{++}$-sucrose) and neutralized PVP-10 (Polyvinylpyrrolidone, Sigma) as described by Myhrvold (1979).

The cell suspensions were frozen immediately in liquid nitrogen at $-196^{\circ} \mathrm{C}$ in $1.5 \mathrm{ml}$ portions in plastic ampullae (Nunc, Inter Med., Denmark). Thawing of the coated SRBC was carried out at $+43^{\circ} \mathrm{C}$ in a water bath after a $15 \mathrm{~s}$ delay with the ampullae at room temperature. After thawing, the cells were washed once in GVBSM $^{++}$-sucrose and twice in PBS. The cells were then resuspended in PBS to obtain working concentrations of cells coated by the $\mathrm{GCH}$ method and by the $\mathrm{CCH}$ method of $3.8 \%$ and $0.66 \%$, respectively. Uncoated SRBC as control were prepared, frozen and thawn in the same way as coated SRBC.

The effect of cryopreservation of coated SRBC was investigated by using freshly coated SRBC and thawed coated SRBC stored at $-196^{\circ} \mathrm{C}$ for 14 and 21 weeks from the same batch in the PHT (Table 1). In the $\mathrm{GCH}$ test, the serum titer of thyroglobulin autoantibodies was generally higher for cryopreserved coated SRBC than for fresh 
Table 1. Effect of cryopreservation of sheep red blood cells coated with thyroglobulin on the passive hemagglutination titer.

\begin{tabular}{|c|c|c|c|c|c|c|}
\hline \multirow[b]{2}{*}{$\begin{array}{l}\text { Dog } \\
\text { no. }\end{array}$} & \multicolumn{3}{|c|}{$\begin{array}{c}\mathrm{CCH}^{\mathrm{a}} \\
\text { Storage time }\end{array}$} & \multicolumn{3}{|c|}{$\begin{array}{c}\mathrm{GCH}^{\mathrm{b}} \\
\text { Storage time }\end{array}$} \\
\hline & Day 0 & $\begin{array}{c}14 \\
\text { weeks }\end{array}$ & $\begin{array}{c}21 \\
\text { weeks }\end{array}$ & Day 0 & $\begin{array}{c}14 \\
\text { weeks }\end{array}$ & $\begin{array}{c}21 \\
\text { weeks }\end{array}$ \\
\hline $1^{*}$ & 40 & 20 & 20 & 20 & 80 & 80 \\
\hline 2 & 40 & 40 & 40 & 20 & 320 & 320 \\
\hline 3 & 160 & 20 & 20 & 20 & 40 & 40 \\
\hline 4 & 80 & 20 & 0 & 40 & 640 & 640 \\
\hline 5 & 40 & 0 & 0 & 20 & 320 & 320 \\
\hline 6 & 20 & 0 & 0 & 20 & 40 & 40 \\
\hline 7 & 40 & 0 & 0 & 20 & 160 & 160 \\
\hline 8 & 160 & 0 & 0 & 80 & 0 & 0 \\
\hline 9 & 20 & 0 & 0 & 0 & 160 & 160 \\
\hline 10 & 20 & 20 & 20 & 0 & 640 & 640 \\
\hline 11 & 0 & $\mathrm{n}$ & $\mathrm{n}$ & 0 & $\mathrm{n}$ & 160 \\
\hline 12 & 0 & $\mathrm{n}$ & $\mathrm{n}$ & 0 & $\mathrm{n}$ & 40 \\
\hline 13 & 0 & $\mathrm{n}$ & $\mathrm{n}$ & 0 & $\mathrm{n}$ & 640 \\
\hline 14 & 0 & $\mathrm{n}$ & $\mathrm{n}$ & 0 & $\mathrm{n}$ & 640 \\
\hline 15 & 20 & $\mathrm{n}$ & $\mathrm{n}$ & 20 & $\mathrm{n}$ & 40 \\
\hline 16 & 160 & $\mathrm{n}$ & $\mathrm{n}$ & 20 & $\mathrm{n}$ & 40 \\
\hline 17 & 0 & $\mathrm{n}$ & $\mathrm{n}$ & 40 & $\mathrm{n}$ & 40 \\
\hline 18 & 80 & $\mathrm{n}$ & $\mathrm{n}$ & 40 & $\mathrm{n}$ & 640 \\
\hline $19^{* *}$ & 0 & 0 & 0 & 0 & 0 & 0 \\
\hline $20^{* *}$ & 0 & 0 & 0 & 0 & 0 & 0 \\
\hline
\end{tabular}

a $\mathrm{CCH}$ - Chromic chloride hemagglutination

b $\mathrm{GCH}$ - Glutaraldehyde hemagglutination

n not done

0 negative (titer $<20$ )

* Titer value expressed as inverse titer value

** Healthy dogs

SRBC. The use of frozen SRBC in the GCH test revealed 5 more hypothyroid dogs with thyroglobulin autoantibodies than when fresh SRBC were used in the $\mathrm{CCH}$ test (Table 1). A possible explanation may be increased ionic strenght between the red cell bound thyroglobulin and the serum anti- bodies, a property achieved during storage at $-196^{\circ} \mathrm{C}$. Increased antibody titers in hemagglutination assay using frozen sensitized SRBC were also observed by Myhrvold \& Akselsen (1982). Antibody-negative control serum did not agglutinate frozen thyroglobulin coated SRBC and antibodypositive serum did not react with frozen unsensitized SRBC. A general decrease in thyroglobulin antibody titers was observed when frozen coated SRBC were used in the $\mathrm{CCH}$ test. This observation may possibly be explained by a change in ionic strength between the metallic cation $\mathrm{Cr}^{3+}$ and the erythrocytes due to altered environment caused by the freezing buffer system. This in turn may lead to extensive loss of thyroglobulin from the RBC surface.

The effect on the PHT titer of coated SRBC stored at $+4^{\circ} \mathrm{C}$ was investigated. Serum samples from 6 dogs with thyroglobulin autoantibodies were used both in the $\mathrm{CCH}$ and in the GCH test. Storage of SRBC coated by the $\mathrm{CCH}$ method was not successful as hemolysis occurred. No effect on the PHT titer was seen when SRBC coated by the $\mathrm{GCH}$ methods were stored at $+4^{\circ} \mathrm{C}$ for 20 days. No agglutination in the PHT was detected when Thymune- $\mathrm{T}^{\mathrm{R}}$ kit was used for detection of canine thyroglobulin antibodies. This study showed that thyroglobulin coated SRBC can be stored at $-196^{\circ} \mathrm{C}$ for at least 21 weeks by using the GCH method. SRBC prepared by the $\mathrm{CCH}$ method had to be used in the PHT immediately after thawing, since a progressive hemolysis was observed soon after thawing, being complete after storage at $+4^{\circ} \mathrm{C}$ for 10 days. We therefore recommend frozen $\left(-196^{\circ} \mathrm{C}\right) \mathrm{SRBC}$ prepared by the $\mathrm{GCH}$ method for use in the PHT to assay autoantibodies against thyroglobulin in dogs. 
Ivar Vollset,

Department of Internal Medicine, Small Animals.

Hans Jorgen Larsen,

Department of Microbiology and Immunology.

Torunn Knavelsrud,

Department of Obstetrics,

The Norwegian College of Veterinary Medicine,

Oslo, Norway.

\section{References}

Avrameas S, Taudou B, Chuilon S: Glutaraldehyde, cyanuric chloride and tetraazotized o-dianisidine as coupling reagents in the passive hemagglutination test. Immunochemistry 1969, 6, 67-76.

Gosselin SJ, Capen CC, Martin SL, Targowski SP: Biochemical and immunological investigations on hypothyroidism in dogs. Canad. J. comp. Med. 1980, 44, 158-168.
Gosselin SJ, Capen CC, Martin SL, Krakowkas: Autoimmune lymphocytic thyroiditis in dogs. Vet. Immunol. Immunpathol. 1982, 3, 185-201.

Mizejewski GJ, Baron J, Poissant G: Immunologic investigations of naturally occurring canine thyroiditis. J. Immunol. 1971, 107, 1152 -1160 .

Myhrvold V: Cryopreservation of sheep red blood cells. Acta vet. svand. 1979, 20, 525-530.

Myhrvold, V, Akselsen JP: The use of frozen erythrocytes in indirect haemagglutination test (HA-test) \& indirect haemagglutination inhibition test (HA test). Thesis. Department of Microbiology, Dental faculty, University of Oslo, Norway 1982.

Vollset I, Larsen HJ: Occurrence of autoantibodies against thyroglobulin in Norwegian dogs. Acta vet. scand. 1987, 28, 65-71

(Received November 3, 1986).

Reprints may be requested from: Ivar Vollset, Department of Internal Medicine, Small Animals, Norwegian College of Veterinary Medicine, P. O. Box 8146, Dep. N-0033 Oslo 1, Norway. 